This is the peer reviewed version of the following article: Page, D. (2015), The visibility and invisibility of performance management in schools. British Educational Research Journal. doi: 10.1002/berj.3185, which has been published in final form at http://dx.doi.org/10.1002/berj.3185. This article may be used for non-commercial purposes in accordance With Wiley Terms and Conditions for self-archiving.

Article first published online: 9 April 2015

\title{
The visibility and invisibility of performance management in schools
}

\author{
Dr. Damien Page \\ University of Greenwich, Avery Hill Campus, Mansion Site, Bexley \\ Road, Eltham, SE9 2PQ. D.page@gre.ac.uk
}




\title{
The visibility and invisibility of performance management in schools
}

\begin{abstract}
This article presents findings from a study of performance management in 10 schools, five primary and five secondary. The aim was to gain a snapshot of how headteachers are interpreting and implementing the reforms to the performance and capability procedures for teachers introduced in September 2013. The findings suggest that the evaluation of teachers is conducted within a context of normalised visibility with evidence of competence collected via observations, learning walks, electronic data, organisational and architectural structures. However, this normalised visibility is contrasted with the normalised invisibility of the actual processes of judgement such as appraisal. Invisibility also frames the management of incompetence, with poorly performing teachers routinely offered 'compromise agreements' to avoid the official capability procedures. The article concludes by highlighting the limits of the panoptic metaphor in a consideration of teacher evaluation and discusses an alternative metaphor, that of glass, with which to view the performance management of teachers.
\end{abstract}

\section{Introduction}

While performance management is deeply embedded within private sector organisations, its transposition to schools is far more recent, becoming formalised (and statutory) in 2000 (DfEE, 2000). The aim of performance management can be understood as bringing together the needs of the individual with the needs of the organisation, to embed personal development and improvement with organisational development and improvement via the tools of evaluation, appraisal and capability procedures. Here, rather than such activities being the stuff of personnel departments, performance management as part of the human resources paradigm becomes integrated into the fabric of management (Purcell and Hutchinson, 2007; McConville, 2006). Of course, although the aims of performance management - organisational success - may be shared between the private and public sectors, what success consists of differs greatly. In the private sector, organisational success may be measured in terms of profit or market share. In schools, however, success is instead measured by pupil achievement and ranking in league tables in an increasingly performative environment: parental choice is more greatly informed by league tables and Ofsted reports; Ofsted have employed almost zero-notice inspections and changed 'satisfactory' to 'requiring improvement'; two gradings of 'requires improvement' places a school into special measures; poorly performing schools are being pressured to become academies (BBC, 2013a). And the more performative the education environment has become, the more stringent the measures of performance management have become. The culmination was in the 2013 reforms that freed headteachers to observe teaching as often as they liked and drastically reduced the length and complexity of the capability and dismissal process.

Against this background, this research aimed to provide a snapshot of performance management in schools to investigate how headteachers had interpreted and implemented the reforms. What was apparent was that in a culture of almost zero-notice inspection, headteachers were keen to ensure the Ofsted-readiness of their schools at all times by making teachers continually visible. Far from the days of internal inspection of pre-identified lessons, teachers now worked within a context of normalised visibility where their performance was available to whoever was there to see it: headteachers would engage in frequent learning walks, entering classrooms unannounced through doorless wide doorways to chat to pupils, check books and question the teacher about what was happening that lesson; in open plan learning spaces teaching and learning was watched by senior leaders whose offices were adjacent, by peers in neighbouring spaces and by the casual visitor who happened to walk by; 
organisational structures were designed to make individual performance visible by having schools-within-schools that contained small departments where underperformance was highly apparent; pupils were asked to provide feedback on their learning (and implicitly their teachers' performance) in interviews with the headteachers. For teachers in the performative school, therefore, work was a matter of normalised visibility. However, while the collection of evaluation evidence was highly visible, the management of poor performance was found to be less visible, clandestine and hidden. Here, away from sight and the official capability procedures, headteachers would hold 'conversations' about the incompetent teacher's future, negotiating 'compromise agreements' to pre-empt lengthy and visible capability processes. In these cases, instead, invisibility was normalised. Therefore, this article presents performance management as a matter of visibility and invisibility and discusses the findings in terms of two metaphors: schools as panoptic and schools as glass organisations.

\section{Performance Management in Schools}

Statutory performance management of teachers in England was introduced in September 2000. Described as the world's biggest performance management system (Mahony and Hextall, 2001, p. 182), the policy sought to develop teachers to 'ensure job satisfaction, high levels of expertise and progression' (DfEE, 2000). As such, performance management would meet the needs of children and raise standards. Drawing on the performance management practices of the private sector (see for example Armstrong, 1994; Lebas, 1995), the policy placed teacher effectiveness at the heart of school effectiveness, attempting to tie together the needs of the school, the individual teacher and pupils. However, the success of the policy was mixed, with varied approaches and commitments arising from the confusion over the meanings and purposes of performance management (Brown, 2005). New regulations were introduced in 2007 (TDA, 2007) that required schools to explicitly demonstrate how performance management linked with strategies for school improvement, self-evaluation and development planning. The policy also identified the sources of evidence that would feed into the performance management cycle including a maximum of three hours of lesson observation per year, staff training and work scrutiny (Morton, 2011). A third round of legislation came into force in September 2013, the first performance management approach of the coalition government (The Education (School Teachers' Appraisal) (England) Regulations 2012) together with a model policy (DfE, 2012a). While the actual content of the reforms is similar in terms of aims and content, there are a number of significant changes. Firstly, the teaching standards - revised by the current government in 2010 - are central to the evaluation of teacher performance and development; secondly, appraisal is tied far more explicitly to recommendation for pay progression; thirdly (and perhaps most controversially), the three hour limit on teaching observations was removed; fourth, the informal stage of capability proceedings was abolished; finally, in a bid to remove poorly performing teachers more quickly, the 'monitoring and review' period following a first warning was reduced in length from 20 weeks to between four and ten weeks. These reforms should be seen within the wider reforms to teaching which removed national regulation of competence with the abolition of the General Teaching Council for England (see Page, 2013) which was often seen as unwilling to bar the 'bad apples' from the profession by certain elements of the media (Daily Mail, 2011; Paton, 2011). As such, the managing of teacher performance was solely in the hands of headteachers, removing the spectre of teacher incompetence from public visibility.

Yet while the issue of performance management is central to the work of teachers, there has been relatively little research on the subject with the majority of it set within a focus on performance related pay rather than the processes of performance management (e.g. Wragg et 
al., 2003; Storey, 2000; Tomlinson, 2000; Haynes et al, 2003). Fidler and Atton (1999) argue that poor teacher performance is the result of past mis-management and that the majority of cases result in improvement as long as headteachers are appropriately determined. As such, they present a structure for managing poor performance that begins with staff selection, cited as a common source of capability issues. However, Fidler and Atton's optimism as to improvement is not shared by other, larger studies that suggest improvement only occurs in $21.5 \%$ of cases dealt with outside of formal procedures and just $12.7 \%$ of cases managed through capability procedures (Earnshaw et al., 2002). Commissioned by the Department for Education and Employment, Earnshaw et al's study found that only $0.67 \%$ of teachers were on capability procedures in 1999-2000 and that 65\% of headteachers had never experienced managing capability issues; where they had been managed, $46 \%$ were managed outside of the official procedures and an additional $40 \%$ at the informal stage. Only $4.8 \%$ of cases ended with dismissal or as a result of the ill-health of the teacher concerned. The study also found that heads were reluctant to confront capability issues because of issues such as competing priorities, a lack of confidence and concern about union involvement. Against this background, Jones et al. (2006) foreground the impact poor teacher performance can have on children's learning, emphasizing the moral imperative of headteachers and teachers themselves to improve their practice through the development of effective self-reflection.

Elsewhere, the literature tends to be almost exclusively critical of the practices of performance management in schools and is discussed within a wider context of performativity, managerialism and marketisation (Gleeson and Husbands, 2003); in this paradigm, performance management is located within managerial rather than professional thinking (Down, Hogan and Chadbourne, 1999). Mather and Seifert (2011) represent many of the themes of this paradigm, situating performance management within New Public Management, modern-day Taylorism 'designed to gain control over craft workers through the separation of task conception and its execution' (ibid, p28). Such an approach, proceeding from a labour process theory framework (see Braverman, 1974), relies on gaining the consent of teachers through perpetuating the 'propaganda' that better teacher performance leads to better 'service provision' adding legitimacy 'to the 'weeding out' of poor performers', those 'challenging' teachers that senior leaders are often unwilling to tackle (Yariv and Coleman, 2005). From this perspective, rather than acting as a means of driving forward quality, it becomes a 'millstone' (Forrester, 2011), a means of surveillance and control that deprofessionalises the workforce. Here, the emphasis is on teaching as performing in a dramaturgical sense, a fabrication of practice in Ball's (2003) terms that prioritises what can be seen: this can be expressed within the pre-occupation with league-tables (Wilson, Croxson and Atkinson, 2004; Perryman et al., 2011) or a rehearsal for an Ofsted inspection (Perryman, 2009; Page, 2013). Here we find a concern with the panopticism of performance management, the Foucauldian (Foucault, 1991) metaphor of constant potential surveillance that aims to create docile bodies capable of self-discipline, an analysis that has been wellrehearsed in education contexts (e.g. Bushnell 2003; Piro 2008; Selwyn 2000). The panopticon was originally a design for a prison by Jeremey Bentham in the late $18^{\text {th }}$ century that arranged individualized prison cells in a circle around a central guard tower. Integral to the design was the fact that prisoners could not tell when the guard tower was staffed, the viewing slats constructed to facilitate the guards looking out but not the prisoners looking in. As such, aware that they could potentially be observed at any time, prisoners would become reflective and would internalize discipline, self-regulating their behaviours under fear of perpetual or potential gaze. Foucault (1991) developed the concept of the panoptic as a metaphor for control in contemporary society and organisations, an efficient means of producing docility as a response to perpetual potential gaze by those in authority. In 
educational contexts, the panoptic is perhaps best personified by Ofsted. Giving almost no notice of an impending inspection, headteachers have little choice but to ensure their schools become self-inspecting (Ferguson et al., 2000; McBeath, 2006) and in a constant state of Ofsted-readiness, ensuring that teachers are performing at a good or better standard at all times. Such measures of performance management have been facilitated by the removal of the three hour a year teaching observation limit allowing headteachers to observe practice whenever they choose. This is perhaps the central point of conflict in the recent reforms of the performance management reforms, attracting strong opposition from the teaching unions (NASUWT, 2013) and individual schools (Baynes, 2013). Yet the panoptic in performance management is not only to be found within inspections and observations - appraisal can also be considered within this perspective, especially as appraisals for teachers pre-date the formalisation of performance management (Whyte, 1986; Bartlett, 2000; Hanney, Seller and Telford, 2003). With shades of the confessional (Barry et al. 2001; Wilson 2002), appraisal can be seen panoptically in two ways: firstly, with an onus on teachers collecting evidence of their performance to inform their appraisal, participants engage in self-surveillance, becoming an informant to the process. Secondly, appraisal involves reflection, a practice analogous to Foucault's (1986) conception of care of the self, the perpetual analysis of the our own behaviours against the prescribed 'regimen' of practice, creating an 'existence dominated by self-preoccupation' (Foucault, 1986, p238). As such, reflection is so embedded within education that its function as a means of self-surveillance (Bleakley, 1999; Clouder and Sellers, 2004) may be overlooked.

Yet there are also those studies that hint at the potential of performance management. In a study of secondary school leaders' perceptions, Moreland (2009) found that performance management could be 'a lifeline' for teachers and managers when the schools were in 'challenging circumstances' ( $p 740$ ): it could act to develop teachers' self-esteem via praise and celebration of their abilities; it could also inform school self-evaluation, allowing senior leaders to increase the effectiveness of under-performing departments. Furthermore, performance management was also seen as vital to the strategic planning within the school by ensuring all staff were aware of the strategic vision. Similarly, Haynes et al. (2003) found that performance management had facilitated greater focus on teachers' practice and a greater awareness of links between individual development and the development of the school. Elsewhere, the potential for teachers to take control of their own performance management, creating a sense of autonomy and control over their work is highlighted (Down, Chadbourne and Hogan, 2000) within more authentic performance management process (Gleeson and Husbands, 2003).

The final element of the reforms concerns those teachers who are deemed not to have met the professional standards required (DfE, 2012b) who can now be dismissed within a term. Previously, in addition to internal disciplinary procedures, poorly performing teachers were subject to a professional disciplinary panel under the GTCE. Now, with issues of incompetence solely an internal matter, teachers have become distanced from comparable professions that retain an independent professional body and hold public hearings for accusations of incompetence. Instead, teachers have shifted away from a paradigm of occupational professionalism with its associated 'collegial authority' with controls 'operationalised by practitioners themselves who are guided by codes of professional ethics which are monitored by professional institutes and associations' (Evetts, 2009, 23-4). Teachers have become ensconced within a paradigm of organisational professionalism that regulates the externally derived regimen of what is good teaching and what 'requires improvement'. Yet the reforms present an overly simplistic view of what constitutes 
incompetence and fails to highlight the difficulties of interpretation. Wragg et al.'s (1999) study of 'failing teachers' found a range of signifiers of incompetence taking in a number of forms that may not be incompetence at all: 'failure to adhere to school policies' and poor 'relationships with teacher colleagues' were cited by a number of headteachers as forms of incompetence, yet in other interpretations such measures may be more akin to teacher misbehaviour (Page, 2012) or even organisational resistance (Fleming and Sewell, 2002; Prasad and Prasad, 1998).

\section{Methodology}

The aim of this research was to gain a snapshot of the performance management practices within schools following the reforms that took effect in September 2013 and to explore how headteachers had interpreted and implemented the reforms. However, rather than just focusing on the design and processes of performance management, I was concerned to investigate how the headteachers viewed the idea of performance management and the impact it had on their school and on their teachers. As such, the aim was to gain an emic perspective rather than to collect data that was generalisable and so the fieldwork involved ten participants, nine headteachers and one director of Human Resources: five were from secondary and five were from primary across three different Local Authorities. Four of the heads were female, three in primary and one in secondary. Two of the secondary schools were academies, the rest were all under their local authority. Purposive sampling was used to select schools that were as varied as possible in terms of the rural-urban continuum and included schools within areas of high social deprivation as well as schools within areas of low levels of deprivation. Once the participants had been recruited, data were collected via semi-structured interviews at each of the schools involved. The interviews lasted between 60 and 100 minutes and were transcribed in full. The analysis of the data began with open coding to identify the major themes before a selective coding approach was used to identify the areas of most interest. In addition to the interviews, three of the participants also gave me a guided tour of key parts of their schools, especially those which had new buildings. One of these tours even involved entering classrooms and observing lessons briefly, an example of a 'learning walk', an important feature of the performance management process. On another, we walked through one of the new open learning areas where teachers acted as facilitators as the pupils worked independently. As such, I had inadvertently become part of the quality monitoring processes that were enacted within the schools, one of the surveyors of teachers' work. In all cases the teachers I encountered seemed unperturbed by the arrival of the head and a visitor in their classrooms and learning spaces; one commented that we had been the second set of observers in 30 minutes, the deputy head having 'popped in' earlier in the lesson. What was also apparent was that the pupils were well used to senior managers entering their classrooms and engaging them in conversation about their learning. Even the architecture contributed to the normalization of learning walks: in two cases there were no doors to the classrooms and the door ways themselves were wider than usual; elsewhere, the new buildings were intentionally open plan to maximize visibility and promulgate new pedagogical approaches. These three tours contributed greatly to the themes that are explored in this article, and are discussed alongside the interview data in the sections below.

\section{Performance Management Overview}

All of the schools had introduced new performance management processes as a result of the government reforms. In the majority of cases, the model proposed by the DfE had been adopted with 'tweaking'. Most of the schools under their local authority had adopted the authority-sanctioned model except Martin (a secondary head) who, because of a lack of speed in his local authority, had used the proposed model from a neighboring authority where he 
had a contact. All of the heads supported the changes and felt that it increased the potential effectiveness of performance management, especially the changes to the capability procedures.

Few of the participants reported any significant consultation with unions or teachers about the changes to performance management. Adopting the model of the DfE and the local authority meant that consultation had been deemed to have already taken place. As such, the heads issued the model to staff and held various sessions explaining the changes. What was significant was that there was little resistance from teachers reported.

Janet (primary): $\quad$ They were consulted but they didn't query any of it. It's on our website so when the government gave out their disciplinary and capability [policy] it was given to the staff and nobody came back and queried it.

While earlier studies documented the lack of clarity amongst headteachers in regards to the purpose and utility of performance management (e.g. Brown, 2005), the participants in this study were clear concerning its centrality to the development of individuals and, therefore, the school. There was a determination to move from seeing appraisal as a tick-box exercise to something more authentic (Gleeson and Husbands, 2003) that could dramatically improve standards. The heads were also determined that teachers would find it a positive experience rather than viewing performance management as a punitive tool:

Interviewer: $\quad$ So do you think your teachers find performance management motivating then?

Tom (secondary): I would hopefully say yes, that would be my nirvana, that the vast majority will find it at the end of the day a positive experience.

In terms of the actual processes, there was consistency across the ten schools: performance management would begin with the appraisal of the headteacher by the governors and advisors and the priorities would then cascade down the hierarchy thereby concretising the connection between individual and organisational needs and objectives. The appraisal of teachers consisted of three objectives in the same areas: pupil attainment, teaching and learning (measured against the Teachers' Standards) and professional development although the exact wording of each varied across the sample.

What was most striking in these practices adopted by the headteachers was the range of strategies for gathering evidence on teacher performance that informed appraisal. The model appraisal and capability model (DfE, 2012a) discusses two means of reviewing performance: firstly, there are 'regular' formal teaching observations; secondly there are times when senior leaders may 'drop-in' to classrooms 'in order to evaluate the standards of teaching and to check that high standards of professional performance are established and maintained' (ibid, p6). In neither case is the frequency of visits specified; instead, frequency is to be decided according to the 'overall needs of the school' and will vary 'depending on specific circumstances'. What this section does not represent is the extent of observations that teachers may be subject to; neither does it represent the additional strategies such as the use of pupil feedback or pupil achievement data. What was apparent from this research was that the strategies of quality assurance concern making the work of teachers perpetually visible. In some cases, this concerns formal observations and 'learning walks'; in other cases it concerns architectural solutions, the creation of open plan classrooms where surveillance is continual and un-hidden; in yet others cases organisational structures are designed to render the 
performance of each teacher more visible. What is clear from the data is the state of normalised visibility that accompanies approaches to performance management, approaches that move beyond evaluating competence towards a state of perpetual Ofsted-readiness. The next section will consider each of these strategies in turn beginning with observations and learning walks.

\section{Visibility: observations and learning walks}

The lifting of the three hour limit on teaching observations was the most contested section of the reforms and was a point of insistence by the NASUWT and NUT unions. The majority of the headteachers in this research retained the three hour limit:

Sue (primary): We don't come near that to be honest and it's not a very union-minded school fortunately for me. I know all the action short of a strike came through and I was aware of that but it didn't affect us in school. And the three hours a year - all our observations are 30 minutes so staff aren't observed anywhere near three hours a year anyway.

However, the participants from the two academies welcomed this section of the reforms:

Interviewer: $\quad$ And it's removed the three hours limit on teaching observations Keith (secondary): Well we ignored that anyway [laughs].

Interviewer: How many would you do on average?

Keith: $\quad$ Well in the past probably three or four; now it could be up to six dependent on the outcomes of the observations.

Peter (secondary): We say we can drop in when we want to observe which is going to be one of the key issues in the policy.

However, while the majority of the participants retained the three hour limit or less, it is important to note that these were formalized, pre-arranged observations. Often teachers were allowed to identify the lesson that they wished to be observed in to lessen the anxiety that observations inevitably conjured but also to give the best representation of their practice possible; as such, they were relatively un-panoptic.

While formal observations were considered valuable, there was a recognition by the heads that, due to the fact they were pre-arranged, their actual usefulness as an indicator of 'real' quality was limited. As such, learning walks were often considered a more valuable means of evaluating teacher performance. However, learning walks were highly variable in nature: in some cases they were formalised and consisted of senior leaders walking around corridors stopping in every classroom; at other times random classrooms would be entered; sometimes they would focus on a specific theme such as feedback, others would be generalised; sometimes observers would observe without interaction, other times they would speak to pupils, check books and question the teachers. The indefiniteness of learning walks was even more pronounced in primary schools. As smaller organisations with greater levels of pupilheadteacher interaction, the primary heads reported that they were in classrooms a great deal anyway; as such, the status of these everyday visits was unclear. What was also unclear was the extent to which learning walks were an official means of evaluating teachers. At one end of the continuum were those heads who were very clear that learning walks would officially inform their judgement: 
Martin (primary): I'm in and out of the class anyway for 10 minutes at a time doing other things. I say to staff, 'you realise when I come in your room, I'm looking. Even if I'm talking to you or passing on a message I will be making a judgement as to what's going on in your room'.

At the other end of the continuum were those heads who stated a separation between performance management and learning walks:

James (secondary): I was very clear about the purpose of learning walks - I don't use learning walks to instigate capability so as a result of a learning walk I wouldn't say 'right, informal meeting, capability, whatever', that's not fair at all.

Thus, while observations were considered a valuable means of informing appraisals, there was a general consensus that learning works provided a much more accurate measure of teacher competence - panoptically, they could happen at any time in any classroom. On the one hand, heads argued that learning walks therefore reduced levels of anxiety, a similar argument used by Ofsted to justify almost zero-notice inspections (Wilshaw, 2012). Instead, as argued by Perryman (2009) and Page (2013), almost zero-notice inspections may normalise anxiety by requiring teachers to be in a constant state of Ofsted-readiness. In addition, in this context, learning walks also helped to normalise visibility.

\section{Visibility: open learning spaces}

Delineating learning walks from other classroom visits was much more difficult in primary schools than secondary. As smaller organisations with fewer staff and less interactional distance between senior leaders and pupils, primary headteachers visited classrooms more often than their secondary counterparts:

Sue (primary): We're very much 'doors are expected to be open', [teachers] know people are in and out all of the time... People just expect that.

Janet (primary): When you walk down the corridor you can see what's going on in the doors as you walk down. If there's a problem then I'd be in.

In these primary schools, open doors to classrooms were normal and so teachers were used to senior leaders and others entering their classes. Again, in these contexts, normalised visibility was an integral part of the culture. It should also be stressed that teaching was not just observed by senior leaders: teaching assistants, peers and teacher-trainees were all regular features of the primary teachers' classroom which helped the normalisation process.

Yet the visibility culture of the primary sector was also found to be influencing secondary schools. Three of the secondary schools had recently completed new building works and visibility had been very much a part of the architecture in several examples: two of the schools had built classrooms without doors and with extra wide doorways so that anyone walking along the corridor could see what was happening. One of these schools had also built a suite of classrooms with glass walls so that, again, even the casual observer could see what was happening. Elsewhere the architectural visibility was even more pronounced. Nicola's school had recently had a completely new building added and, as well as building classrooms without doors, there was a large open plan learning space: 
Nicola (secondary): All of that big space is open so classes are taught alongside each other and it's a very visible, mutually supportive environment because what goes wrong is seen by everybody and supported by everybody... and the extended leadership team are a visible presence in those areas whenever they're not teaching they're there, they've got office spaces with visibility out and a lot of staff will work out in the open areas as well if they've got free periods so they've got an overview as well.

Peter's school, part of a secondary academy chain, was also a new build. After our interview he gave me a tour of the key elements. At the heart of the main building was a wide open area filled with desks, each sporting a computer and books around the outside. The open learning space was literally on the main pathway through the building and so was observable to everyone who passed, teachers, pupils and visitors. Not only this but the upper floors of the building also looked down upon the area as did the glass elevator and glass-walled staircase. Finally, several members of the senior leadership team had offices adjacent to the areas. Here, teachers would set project-based work for pupils who would then work independently while teachers facilitated the activity. There were two justifications for these open space designs: firstly they were an attempt to architecturally force different teaching strategies upon staff, especially approaches that prioritised independent learning, pedagogy that headteachers considered to be favoured by Ofsted. The second justification was that, in Nicola's words, 'bad things happen in closed classrooms'. If there was serious pupil misbehaviour, as the areas were continually visible, assistance could be to hand in a matter of seconds.

\section{Visibility: organisation structure}

Another structural method of creating teacher visibility was organisational rather than architectural and this was apparent in two of the sample schools. Here, the aim was to create schools-within-schools (Raywid, 1996; Lee and Ready, 2007), an approach popularized in the US that creates semi-autonomous sub-units within the main school structure. For example, when Anthony was charged with the redesign of his secondary school, he and the other senior leaders visited America to learn more about the model. When they returned they created a school with three separate schools-within-a-school, each with its own principal and each replicating the main curriculum areas together with a specialism. For example, each school would have its own English and maths department but more resource intensive subjects such as science would become a specialism for one of the mini-schools. One impact of this approach is that the visibility of each teacher was heightened as Anthony explained:

When you break an organisation down into small chunks, both pupils and staff lose the anonymity of large numbers... If you have a large department you can get people hiding and there's collusion to hide... With the small school approach that can't happen because in each one of these schools there are only three teachers [per subject]. Now if one of them is under-performing it's going to have a massive impact on outcomes. That can't be allowed.

In this model, underperformance could be identified more easily because each teacher is much more visible than in large schools. As such, rather than being physically visible, teachers are structurally visible; and with structural visibility comes data-visibility. Each of the heads collected vast amounts of data on their schools which allowed perpetual monitoring: 
Tom (secondary): It's all electronic on databases and there are various people interrogating it. The support teams are interrogating the data, they meet every night to review the day, pick up any issues that have arisen, the senior leadership meet every morning and again they're picking up any issues that have arisen.

In schools-within-schools and in small departments, if the data on pupil attainment does not meet the institutional targets, the teacher responsible can be far more easily identified. Teachers in smaller units have a massive impact both positively and negatively and so by normalizing visibility structurally, underperformance can be identified much more readily, even in the absence of physical visibility.

\section{Student voice}

The final means of collecting data on teacher performance was not detailed in the reforms and involved gathering feedback from pupils; and if learning walks were semi-official methods of making teachers' practice more visible, pupil feedback was even more liminal in the official-unofficial continuum. Again there was a range of practices for collecting pupil feedback: Janet favoured a naturalistic approach and would chat to pupils in the process of learning walks:

Janet (primary): $\quad$ I do walk round the school quite a lot, mainly because I like to be involved with the children so I'll sit and talk to the children and you do pick up - the children here are very vocal [laughs] and we do encourage that.

At the other end of the continuum, headteachers would arrange meetings with pupils to discuss their progress and any concerns they might have. James, a secondary head, held lunches for class representatives; Keith, another secondary head, took the process even further and personally interviewed all students in years 9, 10 and 11, around 220 pupils. The main priority of the meetings was to discuss their progress and to motivate them; however, he did concede that feedback on individual teachers was inevitable.

Keith (secondary): They tell me what's going on. I don't ask [about teachers] but they will tell me - I say I don't ask, I would go through the subjects and say 'ok, English: your target is C, currently you're on a D, are we going to do it?' Sometimes they say 'no' and I say 'why is that' and they say 'I need some help'. Sometimes they say 'I'm going to do it' or 'I'm going to get a B' then I say 'who's your teacher' and that's when they will tell me things.

While student voice was an integral part of the quality procedures within each of the schools, its status as part of performance management was vague. While most of the headteachers claimed that it did not inform their judgement in terms of teacher evaluations, it would be difficult for anyone not to be influenced by pupil reports of poor teaching. Thus, while pupil feedback would unlikely be officially included within appraisals, it acted as another means of rendering teachers visible, with pupils acting as proxy observers in the absence of official observations. 


\section{Invisibility}

As argued in the previous sections, the collection of evidence to inform the judgement of performance is based upon teachers becoming highly visible. However, in stark contrast, the actual process of judgement is largely invisible. Appraisals are confidential matters, discussions and negotiations between the appraiser and appraisee where the conclusions from the data collection exercises are revealed together with the self-reflection (or the selfinforming) by the teachers themselves. For those practitioners who meet their objectives, those whose teaching meets the 'good or better' standard, the appraisal should ideally be a motivating experience and even be linked to progression through the pay spines. For those who do not meet their objectives, for those whose performance is poor, the process becomes even less visible. While the reforms aimed to dismiss incompetent teachers within a term, the heads in this study felt that was an underestimation of the time dismissal takes, time that could be better spent on improving their schools. As such, the management of poorly performing teachers involved strategies outside of the government's capability process.

Keith (secondary): 10 staff left last year at our invitation... Mostly what we do is come to an agreement that 'this is not the right school for you' so they resign or we pay them off. We don't follow the [Local Authority] procedures because you'd still have an incompetent teacher two years after you start the process and we can't afford to do that. So we have a budget of about $£ 30,000$ a year to pay staff off.

Peter (secondary): One of the things I've noticed in education is the amount of compromise agreements that are drawn up, it's huge... You can understand them saying 'I want to get rid of this poorly performing teacher, I don't want to do it in 26 weeks I want to do it quickly', compromise agreement, we get rid of them.

While many of the participants had managed poorly performing teachers, few had ever had to see the process through to the end and the dismissal of the teacher. Much more common were the invisible conversations that took place between headteacher and teacher: the teacher was sat down, the reasons for concern were outlined by the head and the capability process explained together with the potential result of being sacked. Often accompanying this conversation was a common narrative: 'this is not the right school for you; you may do much better in a different school'. The majority of teachers well understood the implicit threat contained within the conversation. They then usually met with their union representative, negotiated a 'compromise agreement' that exchanged cash and a reference (however generic) for a resignation. The heads were therefore saved from lengthy and time consuming capability procedures and the teacher saved themselves from having 'dismissal' on their record. However, while the collection of performance evidence of teachers was highly visible, the process of negotiating exit was invisible, a clandestine event that hid the existence of incompetence. What else the strategy hid was debatable. All of the participants, perhaps unsurprisingly, claimed that a negotiated resignation was the result of a suggestion rather than a threat. How it was experienced by the teachers concerned may well be a different matter.

What was also significant was how the use of compromise agreements by-passed a significant feature of the reforms to the capability process. In the past it was suggested that dismissed teachers who resigned once capability procedures had begun were given satisfactory references as an attempt to induce voluntary exit. As such, poorly performing teachers were able to move from school to school without improving their teaching. The 
reforms therefore attempt to end this 'recycling' process by obliging headteachers to include details of capability procedures in a reference even if staff resigned before dismissal (DfE, 2012c). With a poor reference, teachers were unlikely to resign voluntarily once capability had begun and so the hidden conversation that took place at the beginning was vital - if the teacher resigned before capability began, they could have a reference that made no mention of what was impending. Headteachers were therefore acting within the scope of the reforms and poorly performing teachers left with cash and a reference free from mention of capability. For some of the headteachers, compromise agreements were a matter of pragmatics - they saved everyone's time and they saved their pupils from the impact of poor performance. Others, however, were more conflicted - while the pupils in their own school were delivered from incompetence, compromise agreements would inflict poor performance upon other pupils in other schools:

Nicola (secondary): We then got a point where that person shall we say 'agreed to resign' so that went through in that way and the compromise agreement there was - which I don't like but I had to go along with... The term is well used because I think it compromises me [original emphasis].

The management of incompetence was therefore a matter of invisibility, hiding the conversations that outlined the consequences of resistance and hiding mention of capability in subsequent references.

\section{Discussion}

At an institutional level teachers work within a context of normalised visibility where they are perpetually surveilled, judged and evaluated through a variety of means: observations, learning walks, open learning spaces, organisational structures, electronic data and student voice. In much of the extant literature such surveillance has been framed by the panoptic metaphor, of discipline being internalised via the fear that the docile bodies may be observed at any time. But panopticism relies on the potential for being observed - inmates in Bentham's penal architecture could not tell whether they were being observed as the guard tower was designed so that they could not tell whether the guards were watching or not. It was therefore, according to Foucault, this possibility of observation that created selfdiscipline. Panopticism, after all, functions through 'its discretion, its low exteriorization, its relative invisibility' (Foucault, 1991, p218). It is here, then, that panopticism in relation to the surveillance of teachers is limited, for the means of rendering teachers constantly visible is not always discrete, it is often highly exteriorized and itself very visible. Panopticism relies on anonymity, covertness and the uncertain presence of an observer; in schools, teachers are often well aware that they are being surveilled constantly and they also know who by. While panopticism may still function in terms of 'traditional' means of surveillance such as classroom observations and learning walks by senior leaders, other means of surveillance are less panoptic: data on performance does not reside solely in the headteachers' computer - it is public and shared and overtly informs judgements of competence; organisational structures of small teams facilitates constant performance-visibility; in open learning spaces teachers know they are being watched continually by their colleagues, by senior leaders in their adjacent offices and by visitors and pupils who walk by. Teachers, therefore, do not work within an exclusively panoptic environment; instead, a different metaphor may be more appropriate for this form of normalised visibility. 
Gabriel (2005 and 2008) argues that the contemporary organisation has become a place of glass:

The metaphor of the glass cage suggests certain constraints, discontents, and consolations... Shared features of the glass cage of work and the glass cage of consumption are an emphasis on image, an invisibility of constraints, a powerful illusion of choice, and an ironic question mark as to whether freedom lies inside or outside the glass. Above all, there is an ambiguity as to whether the glass is a medium of entrapment or a beautifying frame (Gabriel, 2008, p311)

On one level, the glass metaphor preserves the fundamental concept of the panopticon with its foregrounding of surveillance. However, with glass, surveillance is overt - the observer can also be seen. Furthermore, by understanding the modern school in terms of glass, we foreground the notion of spectacle, of display, of exposure to the 'critical gaze of the customer' (Gabriel, 2005, p19) - it is a metaphor that raises transparency to a 'supreme value'. From this perspective, rather that viewing teachers within the 'iron cage' of Weber (1958 and 1978), a glass cage may be more appropriate: visible at all times via a variety of means, scrutinised and evaluated via triangulated measures, held up as beatific exemplars of 'good and outstanding' to Ofsted and prospective parents. This glass cage is also proferred as a measure of fairness: 'yes, surveillance may be constant and overt but at least it applies to everyone' is the argument offered. Transparency, therefore, becomes the banner of organisational justice.

But this is not to suggest that the glass metaphor only acts to identify incompetence within classrooms. Glass also acts as a 'framing medium attesting that what is behind it is worthy of attention and admiration' (Gabriel, 2008, p312). In this research I was taken on a learning walk, entering classrooms where pupils were busily engaged in learning, where teachers employed ICT expertly, where the learning objectives were displayed proudly to facilitate the metacognition of the children; on tours I was shown the bespoke open plan learning spaces full of newly purchased PCs and facilitating members of staff. Here, although I was merely a visitor, the 'glass cage' framed what was 'good and outstanding', the Ofsted-inspired aim of all heads and all teachers - if there were classrooms full of disruptive pupils and poor teachers, I was not shown them. Yet the tours I was taken on also highlighted the multiple statuses of headteachers. In one role they are curators of the spectacles on the other side of the glass, framing the performance of their staff for visitors; in another role they are evaluators of the caged, the metaphorical physicians of Foucault (1986) enforcing the regimen of performativity by constantly observing via a variety of measures; finally, they themselves may be considered part of the spectacle: framed by the glass, watched and surveilled themselves by parents, Ofsted and the Department for Education.

Yet while evidence of performance is gathered within a context of normalised visibility, actual judgement is conducted within an organisational blindspot. Appraisals are dyadic, behind closed doors, with shades of the confessional (Barry et al., 2001; Wilson 2002) where teachers engage in critical self-reflection before being confronted with the portfolio of evidence collected from electronic data, learning walks, formal observations, organisational structures and student voice. For those who fail to meet the required standard, capability measures are employed to remove them within a term according to the reforms. However, the data from this research suggested that in many cases, rather than pursue time-consuming processes, teachers were offered deals, 'compromise agreements' with 'incompetent' teachers offered money and a reference if they resigned. Here, then, in stark contrast to the glass cages 
within which the evaluation of performance management takes place, capability proceedings involve the hidden, clandestine deals that circumvent the official procedures. The management of incompetence involves normalised invisibility. Headteachers, therefore, while highly visible within the glass cage themselves in terms of external surveillance, Ofsted inspections, league tables, benchmarking and parental survey responses (see Page, 2013), manage to find a space within which to be hidden, to conduct invisible negotiations to eliminate incompetence from their schools. Visibility is therefore explicitly a matter of organisational power, controlled by senior school leaders in response to their own visibility. Here is the limit of transparency and, in turn, the limit of visibility as a measure of organisational justice. While schools may therefore be understood metaphorically as glass organisations, in places the glass is opaque.

\section{Conclusion}

Since the Conservative/Liberal coalition government came to power, schools have been inundated with new policies and new powers. In a context where 'satisfactory' has become 'requires improvement' and international league tables of performance continue to define policy, the performance of individual teachers has become the prime focus. The reforms to the performance management and capability procedures introduced in 2013 gave increased powers to headteachers to improve their schools, subjecting teachers to potentially unlimited observations and far shorter dismissal processes. Yet the headteachers in this study reported a generally measured approach to performance management that retained the observation limit in most cases. However, it was also clear that this concession to the teaching unions was supplemented by a wide variety of strategies to create an environment of normalised visibility where teachers were continually observed. Yet surveillance was found not to be always panoptic for often it was neither covert nor anonymised; rather surveillance was open and apparent, and distributed between heads, senior leaders, other teachers, pupils and even visitors. From a critical perspective, it can be argued that teachers work within a 'glass cage' that foregrounds transparency and spectacle, rendering the incompetent and the beatific both visible. Yet while transparency may be offered as a measure of fairness and organisational justice, other elements of the performance management process are hidden and invisible, especially in the management of poorly performing teachers. Here, headteachers' practice is obscured from view, enacted through clandestine conversations and negotiations which offer compromise agreements as a means of bypassing highly visible and lengthy capability and dismissal processes. Therefore the visibility of performance in schools is selective and controlled by headteachers. However, it must also be stressed that headteachers themselves are subject to surveillance with the gaze of the Department for Education and Ofsted to be perpetually managed; and this gaze is perhaps the ultimate cause of invisibility as well as visibility of performance.

\section{References}

Armstrong, M. (1994), Performance Management, (London, Kogan Page)

Ball, S. (2003) The teacher's soul and the terrors of performativity, Journal of Education Policy, 18(2), 215-228

Barry, J., J. Chandler, and Clark, H. (2001) Between the ivory tower and the academic assembly line, Journal of Management Studies, 38(1), 87-101

Baynes, C. (2013) Teachers at failing Westwood Girls' College in Upper Norwood strike over lesson observations. Your Local Guardian. Available online at: http://www.yourlocalguardian.co.uk/news/local/topstories/10424040.Teachers_at_fail ing school_strike_over_lesson_observations

BBC (2013a) County chief tells Give to halt 'academy brokers' visits. BBC News. Available 
online at: http://www.bbc.co.uk/news/education-22271467

BBC (2013b)) John Gulson school strike: Teachers 'threatened' by appraisals. BBC News. Available online at: http://www.bbc.co.uk/news/uk-england-coventry-warwickshire22606173

Bleakley, A. (1999) From reflective practice to holistic reflexivity. Studies in Higher Education, 24(3), 315-330

Braverman, H. (1974) Labor and Monopoly Capital (New York, Free Press)

Brown, A. (2005) Implementing performance management in England's primary schools, International Journal of Productivity and Performance Management, 54(5/6), 468481

Bushnell, M. (2003) Teachers in the schoolhouse panopticon: Complicity and resistance. Education and Urban Society, 35(3), 251-72.

Clouder, L. and Sellars, J. (2004) Reflective practice and clinical supervision: an interprofessional perspective, Journal of Advanced Nursing, 46(3), 262-269

Daily Mail. (2011) What DOES it take to get a teacher fired? Part-time stripper and porn star is told he can return to the classroom. Daily Mail. Available online at http://www.dailymail.co.uk/news/article-2032198/Benedict-Garrett-aka-porn-starJohnny-Anglais-CAN-carryteaching.html\#ixzz1lyhuQ0vz

DfE (2012a) Teacher appraisal and capability: a model policy for schools. Available online at:https://media.education.gov.uk/assets/files/pdf/m/model\%20policy\%20rev\%2017\% 20may\%20branded.pdf

DfE (2012b) Teachers' Standards. Available online at: http://webarchive.nationalarchives.gov.uk/20130401151715/https://www.education.g ov.uk/publications/eOrderingDownload/teachers\%20standards.pdf

DfE (2012c) Supplementary guidance on employment checks. Available online at: http://media.education.gov.uk/assets/files/pdf/s/supplementary\%20guidance\%20on\% 20employment\%20checks.pdf

DfEE (2000), Performance Management in Schools: Performance Management Framework, (London, Department for Education and Employment)

Down, B., Hogan, C. and Chadbourne, R. (1999) Making sense of performance management: official rhetoric and teachers' reality, Asia-Pacific Journal of Teacher Education, 27(1), 11-24

Down, B., Hogan, C. and Chadbourne, R. (2000) How are teachers managing performance management? Asia-Pacific Journal of Teacher Education, 28(3), 213-223

Earnshaw, J., Ritchie, E., Marchington, L., Torrington, D. and Hardy, S. (2002) Best practice in undertaking teacher capability procedures. DfEE. Available online at: http://webarchive.nationalarchives.gov.uk/20130401151715/https://www.education.g ov.uk/publications/eOrderingDownload/RR312.pdf

England (2012) The Education (School Teachers' Appraisal) (England) Regulations 2012

Evetts, J. (2009) The management of professionalism: A contemporary paradox. In Changing teacher professionalism: International trends, challenges and ways forward, ed. S. Gewirtz, P. Mahoney, I. Hextall, and A. Cribb, 19-30 (London, Routledge)

Ferguson, N., Earley, P., Ouston, J. and Fidler, B. (2000) Improving schools and inspection: the self-inspecting school (London, Paul Chapman/Sage)

Fidler, B and Atton, T (1999) Poorly Performing Staff in Schools and How to Manage Them, (London, Routledge)

Fleming, P., and Sewell, G. (2002) Looking for the good soldier, Svejk: Alternative modalities of resistance in the contemporary workplace, Sociology, 36(4), 857-73

Forrester, G. (2011) Performance management in education: milestone or millstone? Management in Education, 25(1), 5-9 
Foucault, M. (1986) The history of sexuality vol. 3: The care of the self (London, Penguin) Foucault, M. (1991) Discipline and punish - the birth of the prison (London, Penguin)

Gabriel, Y. (2005) Glass cages and glass palaces: Images of organization in image-conscious time, Organization, 12(1), 9-27

Gabriel, Y. (2008) Spectacles of resistance and resistance of spectacles, Management Communication Quarterly, 21(3), 310-326

Gleeson, D. and Husbands, C. (2003) Modernizing schooling through performance management: a critical appraisal, Journal of Education Policy, 18(5), 499-511

Hannay, L., Seller, W. and Telford, C. (2003) Making the conceptual shift: teacher performance appraisal as professional growth, Educational Action Research, 11(1), 121-140

Haynes, G., Wragg, T., Wragg, C. and Chamberlin, R. (2003) Performance management for teachers: headteachers' perspective. School Leadership and Management, 23(1), 7589

Jones, J., Jenkin, J. and Lord, S. (2006) Developing Effective Teacher Performance (London, Sage)

Lebas, M. (1995) Performance measurement and performance management, International Journal of Production Economics, 41(1-3), 23-35

Lee, V. and Ready, D. (2007) Schools Within Schools: Possibilities and Pitfalls of High School Reform (New York, Teachers College Press)

MacBeath, J. (2006) School inspection and self-evaluation: working with the new relationship (London, Routledge)

Mahony, P. and Hextall, I. (2001), "Performing and conforming", in Gleeson, D. and Husbands, C. (Eds), The Performing School: Managing Teaching and Learning in a Performance Culture (London, Routledge Falmer)

McConville, T. (2006) Devolved HRM responsibilities, middle-managers and role dissonance, Personnel Review, 35(6), 637 - 653

Moreland, J, (2009) Investigating secondary school leaders' perceptions of performance management, Educational Management Administration \& Leadership, 37(6), 735765

Morton, S. (2011) Performance management or managing performance? Supporting a vision to become outstanding, Management in Education, 25(1), 10-14

NASUWT (2013) Call to end deprofessionalising surveillance of teachers. Available online at:http://www.nasuwt.org.uk/Whatsnew/NASUWTNews/PressReleases/CallToEndDe professionalisingSurveillanceOfTeachers

Page, D. (2012) Teacher misbehaviour: An analysis of disciplinary orders by the General Teaching Council for England, British Educational Research Journal, DOI: 10.1080/01411926.2012.674103

Page, D. (2013) The abolition of the General Teaching Council for England and the future of teacher discipline, Journal of Education Policy, 28(2), 231-246

Paton, G. (2011) Just 17 'incompetent' teachers barred from the classroom. The Telegraph. Available online at:

http://www.telegraph.co.uk/education/educationnews/8982966/Just-17-incompetentteachers-barred-from-the-classroom.html.

Perryman, J. (2009) Inspection and the fabrication of professional and performative processes, Journal of Education Policy, 24(5), 611-31

Perryman, J., Ball, S., Maguire, M. and Braun, A. (2011). Life in the pressure cooker school league tables and English and mathematics teachers' responses to accountability in a results-driven era, British Journal of Educational Studies, 59(2), 179-195 
Piro, J. (2008) Foucault and the architecture of surveillance: Creating regimes of power in schools, shrines, and society, Educational Studies 44(1), 30-4

Prasad, A., and Prasad, P. (1998) Everyday struggles at the workplace: The nature and implications of routine resistance in contemporary organizations, Research in the Sociology of Organizations, 15(2), 225-57.

Purcell, J. and Hutchinson, S. (2007) Front-line managers as agents in the HRM-performance causal chain: theory, analysis and evidence, Human Resource Management Journal, 17(1), 3-20

Raywid, M. A. (1996) Taking stock: The movement to create mini-schools, schools-withinschools, and separate small schools. Urban Diversity Series No 108. New York: ERIC Clearinghouse on Urban Education, Teachers College, Columbia University

Selwyn, N. (2000) The National Grid for Learning: Panacea or panopticon? British Journal of Sociology of Education, 21(2), 243-55

Storey, A. (2000) A leap of faith? Performance pay for teachers, Journal of Education Policy, 15(5), 509-523

TDA (2007) Teachers and Head Teachers Performance Management Guidance (London, TDA)

Tomlinson, H. (2000) Proposals for performance related pay for teachers in English schools, School Leadership \& Management, 20(3), 281-298

Weber, M. (1958) The Protestant ethic and the spirit of capitalism (New York, Scribner)

Weber, M. (1978) Economy and society. G. Roth \& C. Wittich, Trans.; G. Roth \& C. Wittich, Eds.; Vols. 1 \& 2 (Berkeley: University of California Pres)s

Wilshaw, M. (2012) High expectations, no excuses. A speech to the London Leadership Strategy's Good to Great Conference, 9 February 2012, in London.

Wilson, D., Croxson, B. and Atkinson, A. (2004) 'What gets measured gets done': headteachers' responses to the English secondary school performance management system, CMPO Working Paper Series No. 04/107. Available online at: http://www.bristol.ac.uk/cmpo/publications/papers/2004/wp107.pdf

Wilson, F. (2002) Dilemmas of appraisal, European Management Journal, 20(6), 620-9

Wragg, E., G. Haynes, C. Wragg, and R. Chamberlin. (1999) Failing teachers? (London, Routledge)

Wragg, T., Haynes, G., Chamberlin, R. and Wragg, C. (2003) Performance-related pay: the views and experiences of 1,000 primary and secondary head teachers, Research Papers in Education, 18(1), 3-23

Yariv, E. and Coleman, M. (2005) Managing 'challenging' teachers, International Journal of Educational Management, 19(4), 330-346 